\title{
PARENT'S STRATEGY TO ATTRACT CHILDREN TO EAT, FEEDING DURATION, AND ITS RELATION TO WEIGHT FOR AGE Z-SCORE IN CHILDREN
}

\author{
Masayu Ramadhani Polanunu${ }^{1}$, Nanda Hudawarrahmah ${ }^{1 *}$, Hartojo ${ }^{2}$, Meta Herdiana Hanindita ${ }^{1}$, Nur Aisiyah \\ Wijaya $^{1}$, Siti Nurul Hidayati ${ }^{1}$ Roedi Irawan ${ }^{1}$, Boerhan Hidajat ${ }^{1}$ \\ ${ }^{1}$ Department of Child Health, Faculty of Medicine, Dr.Soetomo Hospital, Surabaya, Indonesia \\ ${ }^{2}$ Husada Utama Hospital Surabaya, Indonesia \\ *E-mail: nda_hdw@yahoo.com
}

\begin{abstract}
Appropriate feeding practices are critical for gaining and maintaining nutrition and development in children. Previous study in feeding practices indicated that inappropriateness in feeding practices had consequences in children's growth and development. This study aimed to determine corelation between parents strategy to attract children to eat and feeding duration to weight for age z-score in children. This was a simple random sampling, cross-sectional study and held on April to June 2016 in Dr. Soetomo Hospital and Husada Utama Hospital, Surabaya, Indonesia. Subjects in this study were children from 6 to 24 months. Feeding practice determined by interview with children's parents which consisted parent's strategy to attract children to eat, feeding duration, and then children were measured weight for age z-score using WHO chart. Statistical analysis used Spearman correlation test. Thirty children were enrolled, $50 \%$ were male, with median age 16.5 months (6-24 months). Parents strategy to attract children to eat (53.3\% talking, 30\% playing and $16.7 \%$ watching television) had correlated significantly with weight for age $(r=0.35, p=0.028)$. Meanwhile, $56.7 \%$ children with feeding duration more than 30 minutes and $43.3 \%$ children with time feeding duration less than 30 minutes. Feeding duration had no correlation with weight for age in children $(r=-0.32, p=0.43)$. We conclude from this study that parents strategy to attract children to eat had significant correlation to weight for age but feeding duration had no correlation with weight for age. This study implied that strategy to attract children to eat is necessity in children physical development. Meanwhile, feeding duration has no significant implication. We recommended children must be persuaded as part of parents strategy in order to attract them to eat.
\end{abstract}

Keywords: innapropriate feeding practice, children, weight for age

\section{INTRODUCTION}

Feeding practices are essential for nutrition, growth, development, and survival of children. Appropriate feeding practice affects growth and nutritional status whereas an inappropriateness in feeding practices may cause various diseases and result in malnutrition (BDGH, 2007).

Inappropriateness in feeding practices, in such a way that infants and young children received inadequately nutritious diets, infrequently feeding and poorly diversified in the first two years of life, caused more than two-thirds underweight cases related child deaths (Caetano, 2010). Infants and young children are prone to underweight from six months forwards, when breast milk only does not fulfill all nutritional requirements, thus complementary feeding needs to be started (Kandel, 2016).
Failure to gain weight and height are the indicators of growth delayed in infancy. It was estimated that underweight, directly or indirectly lead to almost $60 \%$ mortality in children lower than 5 years (Nasreddine, 2012).

The data from National Health Survey (Riset Kesehatan Dasar/Riskesdas) revealed although there was declining in prevalence of underweight but it is still major problem in pediatric health in Indonesia. Prevalence of underweight according to Health Ministry declined from $19.6 \%$ in 2013 to $17.7 \%$ in 2018 (Kementerian Kesehatan RI, 2018). This study was aimed to determine correlation between parents strategy to attract children to eat and feeding duration to weight for age Z-score in children. 


\section{METHODS}

This was a simple random sampling, cross sectional study held on April to June 2016 at Dr. Soetomo Hospital and Husada Utama Hospital, Surabaya. Subjects in this study were children from 6 to 24 months. These children were randomly selected among patients in outpatient clinic in Dr. Soetomo Hospital and Husada Utama Hospital, Surabaya. Inclusion criteria was children within age range and their parents agreed to join this study. Exclusion criteria were children with malignancy and autoimmune disease. Informed consent was given to their parents or caregivers and approval for joining this study was taken prior the study. This study was approved and gained ethical clearance from Dr. Soetomo Hospital ethical committee (277/Panke.KKE/III/2016).

Thirty children who had been chosen were recorded and their parents were interviewed. Feeding practice was determined by interview who conducted by pediatric residents of Dr. Soetomo Hospital using open question (yes/ no questions), with parents which consisted of parents strategy to attract children to eat and feeding duration. The results were confirmed and validated by pediatrician consultant of nutrition. Then the children were measured using weight for age Z-score using WHO chart. This study used Spearman rank correlation coefficient test in SPSS ${ }^{\circledR}$ ver.23 (significant value, $\mathrm{p}<0.05$ ).

\section{RESULTS AND DISCUSSIONS}

This trial included 30 patients, age between 6-24 months with average ages 16.5 months (Table 1).

Table 1. Patient's Characteristics

\begin{tabular}{lc}
\hline \multicolumn{1}{c}{ Characteristic } & $\mathbf{n}=\mathbf{3 0}(\%)$ \\
\hline Sex & \\
Boy & $15(50)$ \\
Girl & $15(50)$ \\
Age (months) & \\
$6-8$ & $1(4)$ \\
$9-12$ & $5(20)$ \\
$>12$ & $15(60)$ \\
Weight for age & \\
Normal weight & $23(76.67)$ \\
Underweight & $7(23.33)$ \\
\hline
\end{tabular}

Table 2. Correlation between Parents Strategy to Attract Children to Eat and Weight for Age Z-Score

\begin{tabular}{|c|c|c|c|c|}
\hline \multirow{2}{*}{$\begin{array}{c}\text { Strategy to } \\
\text { Attract }\end{array}$} & Normal & Underweight & \multirow{2}{*}{$\mathbf{r}$} & \multirow{2}{*}{$\begin{array}{c}\mathbf{p} \\
\text { value }\end{array}$} \\
\hline & n (\%) & n (\%) & & \\
\hline Playing & $9(30)$ & $0(0)$ & & \\
\hline Talking & $5(16.6)$ & $11(36.7)$ & 0.352 & 0.028 \\
\hline Watching TV & $2(6.7)$ & $3(10)$ & & \\
\hline
\end{tabular}

The first two years are specifically important for children to attain peak nutrition. It is important for them having sufficient nutrition especially in first 6 months by receiving exclusive breast feeding and continued by sufficient complementary feeding through next 23 months (Agrina, 2017).

From interview, 16 from 30 parents were trying to talk to their children while they had meal, 9 from 30 parents were trying to play with their children, and 5 from 30 parents were trying to feed their children while their children watching television (Table 2). Parents strategy to attract children to eat had significant correlation with weight for age $\mathrm{Z}$-score $(\mathrm{r}=0.35, \mathrm{p}=0.028)$.

From table 2, can be drawn that strategy to attract children to eat or to persuade children has significant correlation to weight for age Z-score. Study by Kerzner (2009) described feeding difficulty has general term and wide aspects in feeding problem, include etiology, severity, and consequences. It is manifested in prolonged duration, refused meal, distracted meal time, dependent meal, nocturnal feeding time, distractions for increasing meal, and failed to consume more complex texture.

Previous study also demonstrated that most parents agreed that their children had feeding problem. Study by Kerzner (2009) demonstrated that about $20-60 \%$ parents stated their children had problem such as they did not eat optimally, too picky, eat less, failure to eat more complex food (e.g. more complex texture, variations) or eat "junk food". This study also revealed that in spite of successful, the parents gave several strategies even pressure in order to solve this problem. In addition to this study, it is a necessity for parents having strategy to attract their children to eat.

Although parents employ varieties of strategies to attract children to eat, there is no such 
Table 3. Feeding Rules

\begin{tabular}{ll}
\hline & Regular mealtimes; only planned snacks \\
added & Mealtimes no longer than 30 minutes \\
& Nothing offered between meals except \\
& water \\
& Neutral atmosphere (no forcing of food) \\
& Sheet under chair to catch mess \\
Environment & No game playing \\
& Food never given as reward or present \\
& Small portions \\
& Solids first, fluids last \\
& Self-feeding encouraged as much as \\
& possible \\
& Food removed after 10-15 minutes if child \\
& playing without eating \\
& Meal terminated if child throws food in \\
anger & Wiping child's mouth and cleaning up \\
Procedures & occurs only after meal is completed
\end{tabular}

Reference: Bernard-Bonnin (2006).

as best way for all circumstances and even will be counter productive (Scaglioni, 2008). Nevertheless, consensus in Indonesia advised feeding rules as practical guidence for parents: appropriate in schedule, environment and procedure (Sjarif, 2015) (Table 3).

Meanwhile, we found 13 from 30 children had feeding duration less than 30 minutes and 17 children had feeding duration more than 30 minutes. Feeding duration had no correlation with growth failure $(r=-0.32, p=0.43)$. Thus, feeding duration has inversely proportional relation to weight for age $\mathrm{Z}$-score. The feeding duration in relation to weight for age $\mathrm{Z}$-score in children shown in Table 4.

Although from the study feeding duration has no correlation with weight for age Z-score but in study by Bernard-Bonnin (2015), it is advised that children should be fed less than 30 minutes. Children also should not unnecessarily aroused, burped, or wiped.

Table 4. Correlation between Feeding Duration and Weight for Age Z-Score

\begin{tabular}{ccccc}
\hline $\begin{array}{c}\text { Feeding } \\
\text { Duration } \\
\text { (minutes) }\end{array}$ & Normal & Underweight & & \\
\cline { 2 - 3 } & $\mathbf{n}(\%)$ & $\mathbf{n ~ ( \% )}$ & & p value \\
\hline 30 & $10(33.3)$ & $3(10)$ & 0.05 & 0.489 \\
$>30$ & $13(43.4)$ & $4(13.3)$ & & \\
\hline
\end{tabular}

Infancy and early childhood are pivotal in children development. Nutritious intake plays big role in these pivotal point. It is considered that this pivotal point is important for physical growth and neurologic development. Thus, disturbance in this pivotal point will affect in long term. These processes dependently on children's parents or their caregivers. In previous study, 20-30\% children have feeding problem which results in growth failure (Romano, 2015).

Feeding and eating process are different term. Feeding process is intertwined process between children and their caregiver, eating process is an action by child themselves to get nutritional intake per oral (Silva, 2016). While eating process is complex interaction process from central and peripheral nervous system, oropharyngeal mechanism, cardiopulmonary system, and gastrointestinal tract with support from craniofacial structures and musculoskeletal system. This process depends on child's physiology and developmental stage. In children, this occurs in the context of the caregiver-child dyad (Goday, 2019). In short, in children, feeding process is eating process plus caregiver-child dyad interaction. The applied psychosocial during feeding practices is critical point. Several studies in feeding behaviors intervention was reported and had positive results on children (White, 2017).

Parents strategy to attract their children to eat is strongly correlated to Green's behavioural theory. It is influenced not only by reinforcing factors (e.g. parents), but also by predisposing factors e.g., parents knowledge, their beliefs etc. And by enabling factors e.g. health facilities and health regulation by government (Green, 2002).

This study had limitations. It was held in pediatric outpatient clinic and subjects were only observed for one time when they visited outpatient clinic therefore it was not further observed. Future study is necessary to build on this study results and address its limitation.

\section{CONCLUSION}

Parents strategy to attract children to eat had correlated significantly to weight for age but feeding duration had no correlation to weight for age. 


\section{REFERENCES}

Agrina, Omote, S., Tsuda, A., Okuwa, M., Kimura, R., Syahrul. Et al. (2017). A study of determining factors on underweight among toddlers in Riau, Indonesia. Journal of Wellness and Health Care. Vol 41(1).

Bangladesh Directorate General of Health Services. (2007). National strategy for infant and young child feeding in Bangladesh 2007. Dhaka: Directorate General of Health Services, Ministry of Health and Family Welfare, Government of Bangladesh.

Bernard-Bonnin, A. (2006). Feeding problems of infants and toddlers. Can Fam Physician. 52:1247-51.

Caetano, M.C., Ortiz T.T., da Silva S.G., de Souza F.I., Sarni R.O. (2010). Complementary feeding: inappropriate practices in infants. J Pediatr (Rio J). 86(3):196-201. doi:10.2223/JPED.1994.

Goday PS, Huh SY, Silverman A, Lukens CT, Dodrill P, Cohen SS, et al., (2019). Pediatric Feeding Disorder-Consenses Definition and Conceptual Framework. JPGN.68:124-29.

Green LW. (2002). Health Education Planning, 'A Diagnostic Approach'. Mayfield Publishing Company: California.

Kandel, K.P., Sah, B.K., Kafle, S., Khanal, S., Adhikari, B. (2016). Factors affecting complementary feeding among mothers of under two years children in Darai and Kumal communities Mangalpur, Chitwan. JCMC. 6(18): 24-30. doi:10.3126/jcmc.v6i4.16711.

Kerzner B. (2009). Clinical investigation of feeding difficulties in young children: a practical approach. Clin Pediatr (Phila). 48:960-5. doi: org/10.1177/0009922809336074.

Kerzner B., Milano K., MacLean W.C.Jr, Berall G., Stuart S., Chatoor I. (2015). A practical approach to classifying and managing feeding difficulties. Pediatrics. 135:344-53. doi: 10.1542/peds.2014-1630.
Martini M.G., Taborelli E., Schmidt U., Treasure J., Micali N. (2018). Infant feeding behavious and attitudes to feeding amongst mother with eating disorders: A longitudinal study. Eur Eat Disorders Rev 27(2):1-10.

Nasreddine L., Zeidan M.N., Naja F., Hwalla N. (2012). Complementary feeding in the

MENA region: Practices and challenges. Nutr Metab Cardiovasc Dis. 22:793-8. doi:10.1016/j. numecd. 2012.05.010.

National Health Survey. (2018). Improvement in Nutritional Status. Diakses dari http://www. depkes.go.id/article/view/19013100001/statusgizi-indonesia-alami-perbaikan.html.

Romano C., Hartman C., Privitera C., Cardile S., Shamir R. (2015). Current topics in the diagnosis and management of the pediatric non organic feeding disorders (NOFEDs). Clin Nutr. 34:195-200. doi: 10.1016/j.clnu.2014.08.013.

Scaglioni S., Salvioni M., Galimberti C., (2008). Influence of parental attitudes in the development of children eating behavior. British Journal of Nutrition. 99: Suppl. 1, S22-S25.

Silva G.A., Costa K.A., Giugliani E.R. (2016). Infant feeding: beyond the nutritional aspects. $J$ Pediatr (Rio J). 92(3Suppl1):S2-7. doi: 10.1016/j.jped.2016.02.006.

Sjarif D.R., Yuliarti K., Lestari E.D., Sidiartha I.D.L., Nasar S.S., Mexitalia M. (2015). Praktik pemberian makan berbasis bukti pada bayi dan batita di Indonesia untuk mencegah malnutrisi. Jakarta.

UNICEF. (2013). Key Facts and Figures on Nutrition Report UNICEF. Diakses dari http:// www.unicef.org/media/files/UNICEF_Key_ facts and figures on Nutrition.docx.

White J.M., Begin F., Kumapley R., Murray C., Krasevec J. (2017). Complementary feeding practices: current global and regional estimates. Matern Child Nutr. 13(S2):e 12505:1-12 doi:10.1111/men.12505. 